Gülçay, Çiğdem (2018). “Ustalığın Sırrı: Yetenek mi Kasıtlı Alıştırma mı?”. Uludağ Üniversitesi Fen-Edebiyat Fakültesi Sosyal Bilimler Dergisi, C. 19, S. 34, s. 417450.

DOI: $10.21550 /$ sosbilder.341802

\title{
USTALIĞIN SIRRI: YETENEK Mİ KASITLI ALIŞTIRMA MI?
}

\author{
Çiğdem GÜLÇAY*
}

Gönderim Tarihi: Ekim 2017

Kabul Tarihi: Aralık 2017

\section{ÖZET}

Uzmanlı (expertise) çalışmalarının temel amacl, belirli bir alanda olağanüstü ya da üstün becerilere sahip insanları diğer insanlardan ayıran özellikleri anlamaya ve açıklamaya çalı̧̧maktır (Ericsson ve Smith 1991: 2). Uzman performansını açılklamaya yönelik öne sürülen kuramlardan biri olan kasitlı alıştırma kuramına göre, uzman performansı bireylerin kendi performansını geliştirmek için uzun süre devam eden çabalarının bir sonucudur (Ericsson vd. 1993: 400). Buna göre, farkl uzmanlık düzeylerinde (örneğin, acemi ve usta seviyedeki bireyler) ya da aynı uzman grupları (örneğin, elit sanatçılar) arasında performansta gözlenen bireysel farklılıklar yetenekten ziyade bireylerin yaptıkları kasıtlı alıştırma miktarıyla oldukça yakından ilişkilidir. Kasitlı alıştırma ve uzman performansı arasındaki iliş̧i bugüne kadar birçok farklı alanda incelenmiştir. Bu derleme çalışmasında müzik, satranç ve spor gibi profesyonel uzmanlık alanlarında kasitll alıştırma ve uzman performansı arasındaki ilişkiyi inceleyen çalışmalara yer verilerek uzmanlıkta kasıtlı alıştırmanin rolü incelenmiştir.

Anahtar Kelimeler: Uzmanlık, kasıtlı alıştırma, uzman performansı, üstün beceriler, yetenek

\section{The Secret of Expertise: Talent or Deliberate Practice?}

\section{ABSRACT}

The main purpose of expertise studies is try to understand and explain the characteristics that distinguish people with exceptional or superior skills from other

\footnotetext{
Araş. Gör., Uludağ Üniversitesi Fen Edebiyat Fakültesi Psikoloji Bölümü, cigdemgulcay@uludag.edu.tr

Uludağ Üniversitesi Fen-Edebiyat Fakültesi Sosyal Bilimler Dergisi Uludağ University Faculty of Arts and Sciences Journal of Social Sciences Cilt: 19 Sayl: 34 / Volume: 19 Issue: 34
} 
people in a particular domain (Ericsson and Smith 1991: 2). According to theory of deliberate practice, one of the theories put forward to explain expert performance, expert performance is the result of long term efforts by individuals to improve their performance (Ericsson et al 1993: 400). According to this, the individual differences observed in performance between different levels of expertise (eg, novices and masters) or the same group of experts (eg, elite artists) are closely related to the amount of deliberate practice by individuals. So far, the relationship between deliberate practice and expert performance has been studied in many different domains. The main aim of this review is to examine the role of deliberate practice in expertise, by examinig the relationship between deliberate practice and expert performance in the professional domains of expertise such as music, chess and sport.

Key Words: Expertise, deliberate practice, expert performance, superior skills, talent

\section{GİRIŞ}

Geçmişten günümüze edebiyat, sanat, müzik, spor ve bilim gibi birçok alanda bazı insanlar diğerlerine göre olağanüstü performans göstermişlerdir. Olağanüstü performans gösteren bu insanları diğer insanlardan ayıran özellikler uzun yıllar boyunca merak edilen ve incelenen konulardan biri olmuştur. İlk zamanlarda olağanüstü becerilerin Tanrı'nın bir armağanı olduğu düşünülmüş ve sonrasında yapılan açıklamalarda da bu olağanüstü becerileri doğuştan gelen yeteneğe atfetmeye yönelik bir yanlılık olmuştur (Ericsson ve Charness 1994'ten: 726). Bilimsel çalışmalarla birlikte deneyim ve alıştırmanın/eğitimin de katkısı olduğu kabul edilmeye başlansa da bireylerin ulaşabileceği en üst düzeyin doğal biyolojik kapasitelerle (genetik, zekâ vb.) sınırlandırılacağı belirtilmiş ve beceri edinimine ilişkin çağdaş kuramlarda da bu anlayış sürdürülmüştür (Ericsson 2006'dan: 683-684).

Olağanüstü beceriler sergileyen insanlar, uzmanlık çalışmalarının da temel çıkış noktasını oluşturmaktadır. Genel olarak uzmanlık çalışmaları, belirli bir alanda olağanüstü ya da üstün becerilere sahip insanları hem o alandaki diğer insanlardan hem de genel olarak diğer tüm insanlardan ayıran özellikleri anlamaya ve 
açıklama çalışmaktadır (Ericsson ve Smith 1991: 2). Uzmanlığın doğasını anlamaya yönelik yapılan çalışmalarda iki farklı yaklaşım benimsenmektedir. Mutlak yaklaşımı benimseyen çalışmalarda çeşitli kriterlere göre sadece sıradışı uzmanlar seçilip çalış1lırken, göreli yaklaşımı benimseyen çalışmalarda uzmanlar ve acemiler karşılaştırılmaktadır (Chi 2006: 22). Bununla birlikte, yapılan uzmanlık çalışmalarında "uzman" bireylerin seçilmesinde de farklı yaklaşımlar benimsenmektedir. Yaygın yaklaşımlardan biri olan geleneksel yaklaşımda, uzmanların belirlenmesinde deneyim ya da sosyal temelli bir anlayış benimsenmektedir. Yani, belirli bir alanda uzun yıllar çalışmış kişiler, akranları tarafından uzman olarak tanımlanan kişiler, uzmanlık alanlarında tanınmış/ünlü kişiler "uzman" olarak kabul edilmekte ve incelenmektedir (Ericsson 2006: 686). Ericsson ve Smith (1991: 7) tarafindan öne sürülen "uzman-performans yaklaşımında (expert-performance approach) ise "uzman" kişilerin seçilmesindeki temel kriter laboratuvar ortamında yapılan ve uzmanlık alanlarını temsil eden görevlerde üstün performans gösterebilmedir. Yani bu yaklaşıma göre, uzun yıllar bir işte çalışmak ya da alanında tanınmış olmak uzmanlığın doğasının anlaşılması için yeterli değildir, "uzman" diye belirttiğimiz kişiler laboratuvar ortamındaki alanlarıyla ilgili temsil edici görevlerde tekrarlı bir şekilde üstün performans sergileyebilen kişiler olmalıdır.

Uzmanlık çalışmalarında farklı uzmanlık düzeyindeki bireylerin performanslarını laboratuvar ortamında gerçekleşen deneysel çalışmalarla inceleyen öncü çalışmalardan biri De Groot (1978) tarafindan yapılmıştır. Uzmandan acemiye kadar değişen farklı uzmanlık düzeylerindeki satranç oyuncularıyla kapsamlı deneysel çalışmalar yapan De Groot (1978), yaptığı laboratuvar çalışmalarında sesli düşünme tekniğini kullanarak farklı uzmanlık düzeylerindeki bu satranç oyuncularının hamlelerini karşılaştırdığında uzmanlar ve acemiler arasındaki farklılıklara ilişkin önemli bilgiler elde etmiştir. De Groot (1978) tarafindan yapılan çalışmaları bir adım öteye taşıyan Simon ve Chase (1973), yaptıkları çalışmalarda uzmanlıkta üstün 
performansa ulaşmak için en az 10 yıllık deneyimin gerektiğini belirterek uzman performansında deneyimin rolünü vurgulamışlar ve üstün becerilerin edinilebilir beceriler olduğunu öne sürmüşlerdir. $\mathrm{Bu}$ çalışmalarla birlikte uzmanlık çalışmalarında deneyim, eğitim ve alıştırma yapma gibi faktörlerin uzman performansındaki etkisini incelemeye yönelik çalışmalar artmıştır. Ericsson ve arkadaşları (1993) tarafindan öne sürülen kasıtlı alıştırma kuramı da uzmanların sahip olduğu üstün becerilerin edinilebilir beceriler olduğu varsayımıyla ortaya atılan ve uzman performansını bu doğrultuda açıklamaya çalışan önemli kuramlardan biridir.

$\mathrm{Bu}$ derleme çalışmasında müzik, satranç ve spor gibi profesyonel uzmanlı alanlarında kasıtlı alıştırma ve uzman performansı arasındaki ilişkiyi inceleyen çalışmalara yer verilerek uzmanlıkta kasıtlı alıştırmanın rolü incelenmiştir.

\section{KASITLI ALIŞTIRMA (DELIBERATE PRACTICE)}

Uzman performansını açıklamaya yönelik öne sürülen önemli yaklaşımlardan biri kasıtlı alıştırma kuramıdır (Ericsson vd. 1993). Ericsson ve arkadaşlarına (1993: 400) göre, uzman performans1 bireylerin kendi performansını geliştirmek için uzun süre devam eden çabalarının bir sonucudur. Buna göre, farklı uzmanlık düzeylerinde (örneğin, acemi ve usta seviyedeki bireyler) ya da aynı uzman grupları (örneğin, elit sanatçılar) arasında performansta gözlenen bireysel farklılıklar yetenekten ziyade bireylerin yaptıkları kasıtlı alıştırma miktarıyla oldukça yakından ilişkilidir.

Kasıtlı alıştırma, bireylerin performanslarını geliştirmek için özel olarak tasarlanmış olan aktivitelerdir (Ericsson vd. 1993: 367). Kasıtlı alıştırma aktivitelerinde, başlangıçta bireylerin yapamadığ ancak, alıştırma yaptığı sırada performansın kritik yönlerine odaklanarak ve aldığı geribildirimlerden sonra yaptığı tekrarlar aracılığıyla bireyin performansını kademeli bir şekilde düzelterek ustalaşabileceği görevler yer almaktadır (Ericsson 2006: 692). Bu 
görevler bir öğretmen ya da koç tarafından verilip takip edilebileceği gibi bireyin kendisi tarafından da oluşturulup takip edilebilir.

Kasıtlı alıştırma aktiviteleri iş, oyun ya da belirli bir aktivitenin basit bir şekilde tekrar edilmesi gibi diğer aktivitelerden farklılaşmaktadır. Performans gelişimiyle yakından ilişkili olması, yoğun bir çaba ve konsantrasyon gerektirmesi, doğası gereği eğlenceli/keyifli olmaması kasitlı alıştırma aktivitelerinin temel özelliklerindendir ve bu aktivitelerin diğer türdeki aktivitelerden ayırt edilmesini sağlamaktadır (Ericsson vd. 1993: 368).

Kasıtlı alıştırma kuramına göre, uzman performansındaki gelişmeler, performansın kontrol edilmesine aracılık eden bilişsel mekanizmalardaki değişiklikler ve vücuttaki fizyolojik sistemlerdeki adaptasyonların sonucunda ortaya çıkmaktadır (Ericsson 2006: 698). Bilişsel mekanizmalardaki değişiklikler ve fizyolojik sistemlerdeki adaptasyonlarda performansın gelişimi için özel olarak tasarlanan ve planlanan kasıtlı alıştırma aktivitelerinin uzun yıllar düzenli olarak yapılması önemli bir rol oynamaktadır.

\section{KASITLI KULLANILAN YÖNTEMLER \\ ALIŞTIRMA}

Kasıtlı alıştırmanın uzmanlıktaki rolünü inceleyen çalışmalarda kullanılan yöntemlere bakıldığında geriye dönük ya da ileriye yönelik bilgilerin toplandığ 1 korelasyonel çalışmalar çoğunluktadır. Geriye yönelik bilgilerin toplandığı çalışmalarda araştırmacılar kişilerin geçmişten bugüne kadar toplam birikimli alıştırma miktarı ve türleri ile mevcut performansları arasındaki ilişkiye bakmakta ya da uzman grupları ile amatör grupların alıştırma miktarlarını ve performans düzeylerini karşılaştırmaktadır (Charness vd. 1996; Baker vd. 2005; Campitelli ve Gobet 2008; Charness vd. 2005; Meinz ve Hambrick 2010). İleriye yönelik bilgilerin toplandığ 1 çalışmalarda ise geçmiş bilgilerinin yanı sıra kişilerden birkaç ay boyunca günlük tutmaları istenmekte ve kişilerin bu süre boyunca gerçekleştirdikleri aktiviteler, bunların sıklığı ve süreleri ile kişilerin 
mevcut performansları arasındaki ilişki incelenmektedir (Sloboda vd. 1996; Lehmann ve Ericsson 1998). Bu çalışmalara ek olarak yapılan bazı deneysel çalışmalarda ise, geriye dönük bilgilerin yanı sıra laboratuvar ortamında yürütülen görevlerde uzman ve amatör grupların genel bilişsel beceriler ve alana özgü becerilere ilişkin performansları karşılaştırılmıştır (Ericsson vd. 1993; Lehmann ve Ericsson 1996). Bu çalışmalarda uzman ve amatör gruplar arasındaki farklılıkların genel bilişsel becerilerdeki farklılıklardan mı kaynaklandığı yoksa sadece alana özgü becerilerdeki farklılıklardan mı kaynaklandığı incelenmiştir.

\section{ÇEŞITLI UZMANLIK ALANLARINDA KASITLI ALIŞTIRMA İLE İLGILİ ÇALIŞMALAR}

Uzmanlıkta kasıtlı alıştırmanın rolü bugüne kadar müzik (Sloboda vd 1996; Lehmann ve Ericsson 1996; Ruthsatz vd. 2008), spor (Deakin ve Cobley 2003; Duffy vd. 2004; Soberlak ve Cote 2010; Ward vd. 2007; Young ve Salmela 2010) ve satranç (Campitelli ve Gobet 2008; Bruin vd. 2008) gibi çeşitli alanlar açısından birçok çalışmada incelenmiştir.

Tüm bu çalışmaların ortak noktası, bu alanlarda uzmanların mevcut ya da şimdiye kadar yaptıkları toplam alıştırma miktarı ve türlerine bakarak bireylerin performanslarının ne kadarının yordanabileceğini ve farklı uzmanlık düzeylerindeki bireylerin alıştırma türü ve miktarına bağlı olarak birbirinden ayırt edilip edilemeyeceğini incelemek olmuştur. Eğer kasıtlı alıştırma kuramının varsayımları doğru ise, kasıtlı alıştırma ve performans arasındaki ilişki uzmanlık alanından bağımsız bir şekilde tutarlı olarak ortaya çıkabilmeli ve farklı uzmanlık düzeylerindeki bireyleri de birbirinden ayırt edebilmelidir.

\section{Müzik Alanındaki Çalışmalar}

Başarılı müzisyenleri diğer müzisyenlerden ayıran özellikler geçmişten günümüze merak konusu olmuştur. Müzik yeteneğinin doğuştan mı geldiği yoksa sonradan edinilebilir bir beceri mi olduğu uzmanlık araştırmalarındaki bilimsel çalışmalara da konu olmuştur. 
Bugüne kadar doğuştan gelen yeteneğe atfettiğimiz birçok şeyin uzun yıllar boyunca yapılan yoğun ve çaba gerektiren alıştırmalarla doğrudan ilişkili olduğuna dikkat çeken ilk çalışma Ericsson ve arkadaşları (1993) tarafından yapılmıştır. Araştırmacılar yaptıkları bu çalışmada, farklı performans düzeylerindeki müzisyenleri ( 3 farklı uzmanlık düzeyindeki viyolonistler ile uzman ve amatör piyanistler) müzik ile ilişkili çeşitli aktiviteler açısından karşılaştırarak uzman performansında kasıtlı alıştırmanın rolünü incelemişlerdir. Çalışmaya katılan müzisyenler "tipik bir haftada tek başına alıştırma yapma, diğerleriyle alıştırma yapma, eğlence için çalma" gibi çeşitli müzik aktivitelerine ne kadar zaman harcadıklarını belirterek, bu aktiviteleri "performans geliştirmeyle ilişkisi, çaba gerektirmesi ve eğlenceli/keyifli olup olmaması" açısından değerlendirmişlerdir. Araştırmacılar müzisyenlerden elde ettikleri bu geriye dönük bilgilerin doğrulunu sağlamak için ise, müzisyenlere bir haftalık günlük tutturmuşlar ve ardından bu günlük verileriyle geçmiş bilgileri karşılaştırmışlardır. Tüm müzisyenler tek başına alıştırma yapmayı performans geliştirmeyle en çok ilişkili olan aktivite olarak değerlendirirken, aynı zamanda bu aktiviteyi çaba gerektirmesi açısından yüksek, eğlence düzeyi açısından ise düşük olarak değerlendirmişlerdir. Dolayısıyla, tek başına alıştırma yapmanın müzisyenler için bir kasıtlı alıştırma aktivitesi olduğu görülmektedir. Çalışmada elde edilen sonuçlarda, tek başına alıştırma yapma miktarları açısından gruplar arasında anlamlı farklılıkların olduğu görülmüştür. Performans düzeyi yüksek olan viyolonistler performans düzeyi daha düşük olan viyolonistlerden haftada neredeyse 3 kat daha fazla tek başına alıştırma yaparken, uzman ve amatör piyanistler arasında bu fark neredeyse 10 kat olmuştur. Ayrıca, piyanistlerin birikimli alıştırma miktarları karşılaştırıldı̆̆ında, uzman piyanistlerin bugüne kadar tek başına yaptıkları alıştırma miktarları toplamı amatör piyanistlerden neredeyse 5 kat daha fazla olmuştur. Ericsson ve arkadaşları (1993) yaptıkları bu çalışmada laboratuvarda uyguladıkları görevler ile uzman ve amatör piyanistlerin beceriyle, yani piyano çalma ile ilişkili görevlerdeki ve müzikle ilişkili olmayan görevlerdeki performanslarını da karşılaştırmışlardır. Uzman piyanistler 
beceriyle ilişkili görevlerde amatör piyanistlerden daha iyi bir performans gösterirken, müzikle ilişkili olmayan görevlerde uzman ve amatör piyanistlerin performanslarında bir farklılık olmamıştır. Ericsson ve arkadaşlarına (1993) göre bu bulgular, uzmanların üstün performansının genel bilişsel-motor becerilerden ziyade alana özgü becerilerden kaynaklandığı görüşünü destekler niteliktedir.

Müzik başarısında alıştırmanın rolünü inceleyen bir başka çalışma ise Sloboda ve arkadaşları (1996) tarafindan yapılmıştır. Kasıtlı alıştırmayla ilgili ileriye yönelik bilgilerin toplandığ ilk çalışmalardan biri olan bu çalışmada, farklı başarı düzeylerindeki çok sayıda genç müzisyenin çeşitli alıştırma aktiviteleri karşılaştırılmıştır. Çalışmadaki en başarılı müzisyen grubu oldukça seçici özel bir müzik okulundaki öğrencilerden oluşurken, başarı düzeyi en düşük grup enstrüman çalmaya başlayan ancak 1 yıldan daha az bir sürede formel eğitimi bırakan öğrencilerden oluşmuştur. Katılımcılar ve aileleriyle görüşme yapan ve katılımcıların alıştırma geçmişlerine ilişkin geriye yönelik bilgiler toplayan araştırmacılar, bunun yanı sıra bir grup katılımcıdan da yaptıkları alıştırmalara yönelik 42 hafta boyunca günlük tutmalarını istemiştir. Çalışmada yer alan katılımcılar alıştırma aktiviteleri ile ilgili olarak "kasıtlı alıştırma, doğaçlama çalma, daha önce öğrenilen parçaları çalma ve eğlence amaçlı çalma" gibi çeşitli aktivitelere ne kadar zaman ayırdıklarını bildirmişlerdir. Buna göre, en başarılı gruptaki katılımcılar hem haftalık kasıtlı alıştırma süresi hem de birikimli kasıtlı alıştırma süresi açısından diğer gruplardaki katılımcılardan önemli ölçüde farklılaşmıştır. Örneğin, 12 yaş grubunda en başarılı grupta yer alan katılımcılar haftada yaklaşık 2 saat kasıtlı alıştırma yaparken, diğer 3 grupta bu süre sırasıyla yaklaşık olarak 1 saat, 30 dakika ve 15 dakika olmuştur. Birikimli kasıtlı alıştırma miktarları açısından incelendiğinde, en başarılı gruptaki katılımcıların toplam kasıtll alıştırma miktarı 2500 saatin üzerinde olurken, diğer 3 grupta bu süre sirasıyla 1400,800 ve 400 saat civarında olmuştur. Katılımcıların 42 haftalık bir süreçteki günlük verilerine ilişkin alıştırma türleri ve miktarları karşılaştıııldığında, en başarılı grupta yer 
alan katılımcıların diğer gruplardaki katılımcılara göre daha fazla kasıtlı alıştırma yaptığı, yaptıkları alıştırmalarda teknik ve repertuar egzersizlerine de daha fazla yer verdiği görülmüştür. Sonuç olarak, Sloboda ve arkadaşları (1996) tarafından yapılan bu çalışma, müzik başarısı ile kasıtlı alıştırma miktarı arasında güçlü bir ilişki olduğunu destekleyerek kasıtlı alıştırma miktarının müzikal başarının önemli bir belirleyicisi olduğuna işaret etmektedir.

Sahnede başarılı bir performans sergileyen müzisyenlerin bu performansa hazırlık süreci uzman performansına ilişkin önemli ipuçları sağlayabilmektedir. Uzmanların üstün performansının nasıl bir hazırlık süreci sonucunda ortaya çıtı̆̆ 1 alıştırmanın üstün performansla ilişkisini görmek açısından da önemlidir. Uzman bir piyanistin resitale hazırlık sürecinin yakından incelendiği bir çalışmada araştırmacılar piyanistin resitalde çalacağı parçalarla ilk kez karşılaştığı andan itibaren bir izleyici kitlesi karşısında ilk kez çaldığı ana kadar geçen 9 aylık süre boyunca yaptığı günlük alıştırma aktivitelerini incelemişlerdir (Lehmann ve Ericsson 1998). Yaklaş1k 45-50 dakikalık bir resitalde toplam 8 parça çalacak olan piyanist bu resitale hazırlık süreci boyunca haftada ortalama 17 saat alıştırma yaparken 9 aylık süre boyunca toplam 531 saat alıştırma yapmıştır. Her parça için alıştırma miktarı parçanın zorluğuna göre değişirken parçanın zorluğu arttıkça o parçaya yönelik alıştırma miktarı da artmıştır. Resitale hazırlık süreci boyunca piyanistin toplam alıştırma miktarına resitalde çalacağı parçaların süresi açısından bakıldığında genel olarak bir parçanın her dakikası için neredeyse 15 saat alıştırma yaptığı görülmüştür. Piyanistin gösteri öncesindeki performans kalitesinin gerçekten de uzman performansı niteliğinde olup olmadığı uzmanlar tarafindan değerlendirildiğinde, piyanistin performansının diğer uzmanların performanslarıyla benzer olduğu görülmüştür. Sonuç olarak, yapılan bu çalışma uzman bir piyanistin başarılı performansının uzun bir dönemde yaptığ alıştırmaların önemli bir rolü olduğunu desteklemektedir.

Önceden hazırlanmış bir programın yanı sıra başarılı müzisyenler bazı durumlarda sahnede daha önce hazırlık yapmadığı 
parçalara ilişkin de performans sergileyebilmektedir. İlk kez karşılaşılan bir parçayı hiçbir hazırlık ya da tekrar yapmadan uzman performansı gibi başarılı bir şekilde çalabilme becerisi olan ve "hazırlıksız çalma/okuma" ya da "deşifre" (sight-reading) becerisi olarak adlandırılan bu durum müzik ile ilgili uzmanlık çalışmalarında da incelenen konulardan biri olmuştur. Yapılan bazı çalışmalarda araştırmacılar deşifre becerisinin bir yetenek mi yoksa kasitlı alıştırma sonucunda edinilen bir beceri mi olduğuna yönelik çalışmalar yapmışlardır. Örneğin, Lehmann ve Ericsson (1996) piyanistlerle yaptıkları bir çalışmada, katılımcıların alıştırma geçmişleri ve deşifre ile ilişkili alıştırma aktivitelerine katılımlarını inceleyerek, deşifre performansındaki bireysel farklılıkların bu beceri ile ilişkili kasıtlı alıştırma aktivitelerine katılımla açıklanıp açıklanamayacağını araştırmışlardır. Ayrıca, deşifre becerisi ile ilişkili olduğunu düşündükleri hatırlama, doğaçlama ve kinestetik becerilere yönelik deneysel görevler tasarlayarak piyanistlerin bu görevlerdeki performansı ile deşifre performansı arasında bir ilişki olup olmadığını da incelemişlerdir. Yapılan bu çalışmada araştırmacılar, katılımcıların deneysel görevlerdeki performansları ile deşifre performansı ve kısa bir tekrardan sonra çalma performansı arasında anlamlı korelasyonlar bulmuşlardır. Örneğin, katılımcılardan biraz önce çaldıkları parçayı yeniden hatırlayıp çalmalarının istendiği bellek görevlerinde yüksek performans gösteren katılımcıların kısa bir tekrardan sonra çalmada da yüksek performans gösterdiği görülmüştür. Doğaçlama görevlerinde yüksek performans gösteren katılımcıların hem deşifre hem de kısa bir tekrardan sonra çalma performanslarının da yüksek olduğu görülmüştür. Katılımcıların deşifre performanslarıyla geçmişteki alıştırma türleri ve miktarları arasındaki ilişki incelendiğinde, eşlik ederek çalma deneyimleri ile eşlik ederek çalma repertuarları deşifre ve kısa bir tekrardan sonra çalma performansını yordayan en önemli değişkenler olmuştur. Ancak alıştırmaların miktarının yanı sıra niteliğine de dikkat çeken araştırmacılar sadece deneyimin kendisinin ya da repertuar sayısının değil, aynı zamanda çalınan parçaların karmaşıklık ve zorluk düzeylerinin de önemli olduğuna işaret ederek deşifrede daha yüksek 
performans göstermek için karmaşıklık ve zorluk düzeyi giderek artan parçalarla alıştırma yapmanın önemli olduğunu belirtmişlerdir. Sonuç olarak, yapılan bu çalışmada deşifre becerisinin doğuştan gelen bir yetenekten ziyade alana özgü aktivitelere uzun süreli kasitlı katılımla ilişkili olduğu öne sürülmüştür. Yapılan deneysel çalışmalarda da, deşifre becerisinin sürekli ve performans geliştirici alıştırmalarla geliştirilebilecek bir beceri olduğunu destekleyen bulgular elde edilmiştir. Örneğin, Dalkıran (2011), yaptığı bir çalışmada hatalara yönelik geribildirimler doğrultusunda düzenlenen performans geliştirici alıştırmaların deşifre becerisini geliştirmede etkili olup olmadığ 1 incelemiştir. Keman öğrencileriyle yaptığı bu çalışmada, öğrencilerin deşifre sırasında yaptıkları hataları sınıflandıran araştırmacı, deney ve kontrol grubu olmak üzere 2 grup oluşturduktan sonra deney grubunda yer alan öğrencilere metronom destekli alıştırma eğitiminin yer aldığı 4 haftalık bir alıştırma programı uygulamıştır. Çalışma sonunda, deney grubunda yer alan öğrencilerin deşifre performanslarını kontrol grubuna kıyasla anlamlı derecede geliştirdiği görülmüştür. Piyano öğrencilerine deşifre becerisi kazandırmayı amaçlayan bir çalışmada da piyano öğretiminde deşifre becerisi için geliştirilmiş parçalarla 13 hafta boyunca her hafta 10 dakika süreyle deşifre becerisini geliştirmeye yönelik alıştırmalar yapılmıştır (Özer ve Yiğit 2011). Çalışma sonunda düzenli alıştırma yapılan grubun kontrol grubuna kıyasla deşifre performansında anlamlı artışların olduğu görülmüştür. Deşifre becerisinde kasıtlı alıştırmanın önemli bir rolü olduğunu belirten bu çalışmaların yanı sıra, deşifre becerisinde kasıtlı alıştırmanın gerekli ancak yeterli olmadığını belirten çalışmalar da bulunmaktadır. Örneğin, Meinz ve Hambrick (2010)'e göre, çalışma belleği kapasitesi de deşifre performansında doğrudan rol oynamaktadır. Farklı uzmanlık düzeyindeki piyanistlerle yaptıkları çalışmada piyanistlerin kasıtlı alıştırma miktarları ve çalışma belleği kapasitelerinin deşifre performansı ile ilişkisini inceleyen araştırmacılar, piyanistlerin hem genel kasıtlı alıştırma miktarı hem de deşifreyle ilgili kasıtlı alıştırma miktarının daha yüksek deşifre performansıyla ilişkili olduğunu bulmuş̧tur. Bununla birlikte, kasıtlı alıştırma miktarından bağımsız bir 
şekilde daha yüksek çalışma belleği kapasitesi daha yüksek deşifre performansıyla ilişkili olmuştur. Kasıtlı alıştırma aktiviteleriyle ilgili olarak, sadece deşifreyle ilgili olan kasıtlı alıştırma aktivitelerinin değil genel olarak kasıtlı alıştırmayla ilişkili diğer aktiviteler de deşifre performansını arttırmıştır. Kasıtlı alıştırma miktarı deşifre performansının neredeyse yarısını tek başına açıklayabilse de, çalışma belleği kapasitesinin eklenmesi bu etkiyi bir miktar daha arttırmıştır. Deşifre performansında çalışma belleği kapasitesinin az da olsa bir etkisi olmasına bağlı olarak Meinz ve Hambrick (2010), uzun süreli kasıtlı alıştırmaların hazırlıksız çalmada üst düzey performansa yol açabilse de çalışma belleği kapasitesinin performanstaki ulaşılabilecek en üst düzeyi sınırlayacağını öne sürmüştür. Meinz ve Hambrick (2010) çalışma belleğinin değiştirilemez temel bir yetenek olduğunu belirtseler de kapsamlı tekrarlar ve uygun bellek stratejileri kullanılarak belleğin geliştirilebilecek bir beceri olduğunu gösteren çalışmalar da bulunmaktadır (Ericsson vd. 1980).

Kasıtlı alı̧şırmanın sadece uzman performansın ediniminde değil, aynı zamanda ulaşılan uzman performansın sürdürülmesinde/korunmasında da önemli bir rol oynadığına işaret eden çalışmalar bulunmaktadır. Genç ve yaşlı piyanistlerde uzman ve amatör grupların kasıtlı alıştırma miktarlarıyla performans düzeyleri arasındaki ilişkiyi inceleyen Krampe ve Ericsson (1996) yaptıkları çalışmada bu grupları hem genel bilişsel beceriler hem de alana özgü beceriler açısından karşılaştırmıştır. Buna göre, genel bilişsel becerilere ilişkin görevlerde hem uzman hem de amatör gruptaki yaşlı piyanistlerde performansta benzer şekilde yaşa bağlı büyük düşüşler görülmüştür. Müzik ile ilgili görevlerde ise, yaşlı amatör piyanistlerde yaşa bağl1 büyük düşüşler görülürken, yaşlı uzman piyanistlerin performansında oldukça küçük düşüşler olduğu görülmüştür. Müzikle ilişkili görevlerdeki performansları yordamada kasıtlı alıştırmanın etkisi incelendiğinde ise, yaşlı amatör piyanistlerde performanstaki yaşa bağlı düşüşler kasıtlı alıştırma miktarından bağımsız olarak ortaya çıkarken, yaşlı uzman piyanistlerde performansta yaşa bağlı düşüşler ile kasıtlı 
alıştırma miktarı arasında güçlü bir ilişki ortaya çıkmıştır. Kasıtlı alıştırma miktarıyla ilgili ölçümlerde müzikle ilişkili tüm görevlerdeki performansı yordayan en güçlü değişken ise son 10 y1ldaki kasıtlı alıştırma miktarı olmuştur. Müzikle ilişkili görevlerdeki performansta hem gruplar arası farklılıkların hem de yaşlı uzman grubundaki piyanistlerde bireyler arasındaki farklılıkların açıklanmasında son 10 yıldaki kasıtlı alıştırma miktarının önemli bir rolü olduğu görülmüştür. Sonuç olarak, yapılan bu çalışmada elde edilen bulgular uzman performansının ileri yaşlarda sürdürülmesinde /korunmasında da kasıtlı alıştırmanın önemli bir rolü olduğunu desteklemekte ve performansta gözlenen bireysel farklıların kasıtlı alıştırma miktarı ile yordanabileceğine işaret etmektedir.

Uzman performansında kasıtllı alıştırmanın önemli bir rolü olduğunu belirten bu çalışmaların yanı sıra bazı araştırmacılar kasıtlı alıştırmanın uzman performansını açıklamada yeterli olmadığını öne sürmüştür. Örneğin, Ruthsatz ve arkadaşlarına (2008) göre, genel zekâ ya da müzikal yetenek gibi faktörler de müzikal başarıda önemlidir. Yaptıkları çalışmada genel zekâ, alana özgü müzikal beceriler ve alıştırma miktarı ile müzikal başarı arasındaki ilişkiyi iki farklı müzisyen grubu açısından (lise düzeyi ve konservatuar düzeyi) incelemişlerdir. Lise düzeyindeki müzisyen grubu açısından karşılaştırıldığında genel zekâ, alana özgü müzikal beceriler ve alıştırma miktarı değişkenlerinin her biri müzikal başarı ile ilişkili bulunurken, en yüksek korelasyon alıştırma miktarı ve müzikal başarı arasında olmuştur. Konservatuar düzeyindeki müzisyen grubu açısından karşılaştırıldığında ise, birikimli alıştırma miktarı ile müzikal başarı arasında anlamlı bir ilişki bulunurken, hem genel zekâ ve müzikal başarı arasında hem de alana özgü müzikal beceriler ve müzikal başarı arasında anlamlı bir ilişki ortaya çıkmamıştır. Müzikal başarının yordanmasında değişkenlerin etkisine bakıldığında, lise düzeyindeki müzisyen grubunda müzik başarısının yordanmasında her bir değişken bir miktar etkili olurken, müzik başarısını yordayan en iyi koşul 3 değişkenin de birlikte yer aldığ 1 koşul olmuştur. Buna bağlı olarak, 
araştırmacılar genel zekâ ve müzikal yetenek faktörlerini de müzikal başarıda rolü olan temel faktörler olarak değerlendirmiştir. Ancak, konservatuar düzeyindeki müzisyen grubu açısından incelendiğinde ise, müzikal başarıyı yordayan tek değişken birikimli alıştırma miktarı olmuştur. Buna karşın, araştırmacılar bu üst düzey grupta genel zekâ ve müzikal yeteneğin müzikal başarıyla bir ilişkisinin olmamasını, lise düzeyindeki gruba göre bu grubun zaten genel zekâ ve müzikal yetenek açısından oldukça seçici kişilerden oluşmasıyla açıklamışlardır. Sonuçta, Ruthsatz ve arkadaşları (2008) alıştırmanın uzman performansında aracı bir faktör olduğunu, ancak bunun için de söz konusu grubun zekâ ve müzikal yetenek açısından oldukça seçici kişilerden oluşması gerektiğini belirtmişlerdir. Yapılan bu çalışmayı kasıtlı alıştırma kuramı açısından ele aldığımızda öne çıkan faktörlerden biri müzikle ilişkili becerilerin bu çalışmada "müzikal yetenek" olarak değerlendirilmesidir. Araştırmacılar katılımcıların tonal yetenek ve ritim alt testlerinin bulunduğu bir testteki ("Advanced Measures of Music Audiation" testi) performanslarını müzikal yeteneğin göstergesi olarak ele almış olsalar da kasıtlı alıştırma kuramı açısından değerlendirdiğimizde aslında katılımcıların bu testteki performansları da alıştırma miktarından etkilenmektedir. Dolayısıyla, "müzikal yetenek" olarak belirtilen değişken alıştırma miktarını da kısmen kapsamaktadir.

Kasıtlı alıştırmanın uzman performansındaki rolü bazı metaanaliz ve benzeri çalışmalarla da incelenmiştir. Ancak, çalışmalarda çelişkili sonuçlar elde edilmiştir. Müzikal performansta kasıtlı alıştırmanın etkisini incelemek için meta-analiz çalışması yapan Platz ve arkadaşları (2014) göreve özgü alıştırma ve müzikal başarı arasında yüksek bir ilişki bularak kasıtlı alıştırmanın müzikal başarıda önemli olduğunu belirten çalışmaları destekleyen sonuçlar elde etmiştir. Buna karşın, müzik alanında kasıtlı alıştırmayla ilişkili bulguları yeniden analiz ederek uzman performansında kasıtlı alıştırmanın rolünü inceleyen Hambrick ve arkadaşları (2014) kasıtlı alıştırma ve müzik performansı arasında yüksek bir ilişki bulsa da kasıtlı alıştırmanın 
müzik performansına ilişkin varyansın sadece \%30'unu açıkladığını belirterek kasıtlı alıştırmanın müzik performansındaki bireysel farklılıkları açıklamada yeterli olmadığını öne sürmüşlerdir. Hambrick ve arkadaşlarına (2014) göre kasıtlı alıştırmanın yanı sıra başlangıç yaşı, zekâ, kişilik ve genetik faktörler de uzman performansında etkili olabilir.

\section{Satranç Çalışmaları}

Satranç, genellikle zekâ ile ilişkili olarak düşünülse de yapılan çalışmalar zekânın satranç performansını güvenilir bir şekilde yormadığına, ortalama bir zekâ ile de büyük bir satranç ustası olunabileceğine işaret etmektedir (Colvin 2008: 44).

Satranç oyuncularının üstün performanslarının genel zekâdan ziyade alana özgü becerilerle ilişkili olduğu görülmektedir. Satranç uzmanları ile normal bireyler arasındaki farklılıkların incelendiği ilk çalışmalardan birinde bir grup Rus araştırmacı aralarında dünya şampiyonlarının da bulunduğu satranç uzmanları ile satranç oyuncusu olmayan bireyleri bellek, dikkat, zihinsel problemleri çözme hızı ve doğruluğu açısından karşılaştırdıklarında her iki grup da neredeyse bütün testlerde benzer puanlar alırken, uzmanlar sadece satrançla ilişkili görsel bellek görevlerinde satranç oyuncusu olmayan bireylere göre daha iyi performans göstermiştir (Hearst ve Knott 2008'den: 152-153). Acemiden büyükustaya kadar değişen farklı beceri düzeylerindeki satranç oyuncularıyla kapsamlı deneysel çalışmalar yapan De Groot (1978) da satrançla ilişkili bellek görevlerindeki performansın bireylerin satranç düzeyiyle yakından ilişkili olduğunu göstermiştir. Örneğin, bir büyükusta çok kısa bir süreliğine baktığ 22 satranç taşının yerini tamamıyla doğru bir şekilde hatırlayabilirken, uzmanlık seviyesi daha düşük olan bir kişi 22 taştan sadece 9'unun yerini doğru bir şekilde hatırlayabilmiştir. Satranç uzmanlarının üstün bellek performanslarının örüntü tanıma ile yakından ilişkili olduğunu öne süren Simon ve Chase (1973), bu becerilerin edinilmesinde deneyimin rolüne dikkat çekerek bu üstün performansa ulaşmak için en az 10 yıllık deneyimin 
gerektiğini belirtmişlerdir. Dolayısıyla, Simon ve Chase (1993: 403)'e, bir satranç ustası olmak için ne yapmak gerektiği sorulduğunda alacağımız cevap "binlerce saatlik alıştırma"dır. Ericsson ve arkadaşlarının (1993) kasıtlı alıştırma kuramının öne sürülmesinde önemli bir katkısı olan bu çalışmayla birlikte satranç becerileri ve alıştırma arasındaki ilişki de uzmanlık çalışmalarında yaygın olarak incelenen konulardan biri olmuştur. Çeşitli satranç aktivitelerine katılımla bireylerin satranç performansları arasındaki ilişkiyi inceleyen çalışmalarda kasıtlı alıştırmanın önemli bir rolü olduğunu belirten çalışmaların yanı sıra kasıtlı alıştırmanın gerekli ancak yeterli olmadığını belirten çalışmalar da bulunmaktadır (Charness vd. 2005; Bruin vd. 2008; Gobet ve Campitelli, 2007; Hambrick vd. 2014).

Satranç becerilerin gelişiminde deneyimin önemli olduğunu gösteren çalışmalar bulunsa da (Horgan ve Morgan 1990) yapılan çalışmalar tek başına ciddi çalışma yapmanın uzman performansında daha önemli olduğuna işaret etmektedir. Satranç oyuncularının tek başına ciddi alıştırma yaptıkları aktivitelere baktı̆̆ımızda bu oyuncuların yaygın olarak kullandıkları stratejilerden birinin dünyadaki en iyi satranç oyuncuları arasındaki oyunların yayınlarını analiz etmeleri olduğu görülmektedir (Ericsson 2006: 697). Bu alıştırmalar boyunca oyunu adım adım oynayarak analiz eden satranç oyuncuları her adımda önce kendileri hamle yaparlarken daha sonra satranç ustalarının orada hangi hamleyi yaptığına bakmakta ve nerede hata yaptıklarını, neyi gözden kaçırdıklarını bulmaya çalışmaktadırlar. Dolayısıyla, kasıtlı alıştırma açısından bakıldığında, performansı geliştirmek amacıyla yapılan ve yoğun dikkat ile çaba gerektiren bu aktivitelerin kasıtlı alıştırma aktivitelerinin güzel bir örneği olduğu görülmektedir. Bireylerin kendi kendilerine çalışarak da satranç becerilerini geliştirebileceğini düşünen Charness ve arkadaşları (1996) yaptıkları bir çalışmada alıştırma ve antrenörlüğün/eğitmenliğin satranç becerilerinin gelişimindeki rolünü incelemişlerdir. Orta düzey, usta ve büyükusta gibi farklı uzmanlık düzeylerindeki satranç oyuncularını yaş, beceri, alıştırma yapma ve antrenöre/eğitmene sahip olup olmama gibi çeşitli 
faktörler açısından karşılaştıklarında antrenöre/eğitmene sahip olma ile mevcut satranç puanları arasında bir ilişki ortaya çıkmazken, satranç becerisini yordayan en güçlü değişken birikimli tek başına ciddi analiz miktarı yani kasıtlı alıştırma olmuştur.

Kasıtlı alıştırmanın uzman performansını güçlü bir şekilde yordamasının yanı sıra elit ve orta düzey satranç oyuncularını da güçlü bir şekilde birbirinden ayırdığını gösteren çalışmalar da bulunmaktadır. Charness ve arkadaşları (2005) tarafından yapılan ve satranç oyuncularının çeşitli satranç aktivitelerine (tek başına ciddi çalışma, turnuvalarda oynama, satranç eğitimi alma vb.) katılım sıklıkları ve sürelerinin incelendiği bir çalışmada orta düzey ve en üst düzey satranç oyuncularının (büyükusta) yer aldığı örneklemde mevcut satranç becerisini yordayan tek değişken tek başına ciddi çalışma saati olmuştur. Katılımcıların 10 yıl boyunca yaklaşık toplam tek başına ciddi çalışma yaptıkları saatler karşılaş̧ırıldığında elit düzeydeki satranç oyuncuları (büyükusta) toplam yaklaşık 5000 saat tek başına ciddi çalışma yaparken, orta düzey satranç oyuncularında bu süre yaklaşık 1000 saat olmuştur.

Satranç performansında bireysel çalışmaların önemini vurgulayan çalışmaların yanı sıra grup çalışmalarının da önemli olduğunu belirten çalışmalar bulunmaktadır. Örneğin, Campitelli ve Gobet (2008)'e göre, grup alıştırmaları üst düzey satranç performansında bireysel alıştırmalara göre daha iyi bir yordayıcıdır. Satranç uzmanlığının ediniminde alıştırmanın rolünü inceleyen araştırmacılar, antrenörlük/eğitmenlik, körlemesine satranç, hızlı satranç oyunu oynamayı grup alıştırmaları olarak değerlendirirken; körlemesine satrançla ilgili okuma yapma, geçmiş oyunlara ilişkin veritabanlarını kullanma, satranç programlarını kullanma ve sahip olunan kitap sayısını bireysel alıştırma olarak değerlendirmiştir. Yapılan bu çalışmada, orta düzey, uzman ve büyükusta satranç oyuncularının alıştırma türleri ve miktarları karşılaş̧ırıldığında, her iki alıştırma türü ile mevcut satranç becerisi arasında güçlü bir ilişki ortaya çıkarken, grup alıştırma miktarındaki ilişki bireysel alıştırma miktarına 
göre daha yüksek olmuştur. Ancak, yapılan bu çalışmada her ne kadar araştırmacılar grup alıştırmalarının daha önemli olduğunu belirtseler de araştırmacıların bireysel ve grup alıştırmaları olarak değerlendirdiği aktivitelere baktığımızda bireysel alıştırmaların tek başına ciddi çalışma saatlerinden ziyade satranç programlarını kullanma ya da sahip olunan kitap sayısı gibi değişkenlerle ölçüldüğü görülmektedir. Dolayısıyla, bu çalışmada incelenen bireysel alıştırma aktivitelerinin tam olarak kasıtlı alıştırmayı yansıttığı söylenemez.

Satranç ile ilişkili yapılan çalışmalarda sadece üstün performansın değil aynı zamanda üstün performansa ulaşamadan satranç eğitimini bırakan bireylerin performanslarının da kasıtlı alıştırma ile yordanabileceğine işaret eden çalışmalar bulunmaktadır. Örneğin, Bruin ve arkadaşları (2008) tarafindan yapılan ve kasıtlı alıştırma ile satranç performansı arasındaki ilişkinin incelendiği bir çalışmada, Hollanda Satranç Federasyonunun en üst düzeydeki ulusal satranç eğitimlerine katılıp devam eden satranç oyuncuları ile bu eğitimlere katılıp bir süre sonra bırakan satranç oyuncuları ciddi bir şekilde satranç oynamaya başladıkları ilk yıldan itibaren gerçekleştirdikleri satrançla ilişki alıştırma aktiviteleri açısından karşılaştırılmıştır. Katılımcılardan elde edilen geriye yönelik bilgilerin doğruluğunu sağlamak amaciyla araştırmacılar 3 hafta boyunca katılımcılardan günlük tutmalarını istemiştir. Buna göre, tek başına ciddi çalışma ve diğerlerine karşı ciddi satranç oyunu satranç performansına güçlü bir katkı sağlamaktadır. Buna ek olarak, kasıtlı alıştırma miktarı sadece mevcut satranç performansı ile değil, aynı zamanda zaman içindeki satranç performansı ile de ilişkili olmuştur. Başlangıçta ulusal eğitime seçilirken her iki grup da benzer satranç puanlarına sahip olsa da, eğitimi bırakanların satranç puanları zaman geçtikte diğer grubun gerisinde kalmıştır. Ancak, yapılan bu çalışmada elde edilen en önemli bulgulardan biri ise, satranç eğitimine devam eden ve bırakan oyuncuların kasıtlı alıştırma aktivitelerinden benzer şekilde yararlandığının gösterilmesidir. Bu bulgulardan yola çıkan araştırmacılar, ulusal satranç eğitimini bırakan oyuncuların daha düşük 
performans düzeylerinin bu oyuncuların kasitlı alıştırma aktivitelerinden daha az yararlandıkları için değil, kasıtlı alıştırmaya daha az zaman harcadıkları için olabileceğini öne sürmüşlerdir.

Kasıtlı alıştırmanın satranç performansında önemli bir rolü olduğunu belirten bu çalışmaların yanı sıra kasıtlı alıştırmanın gerekli ancak yeterli olmadığını belirten çalışmalar da bulunmaktadır. Örneğin, Gobet ve Campitelli (2007)'ye göre, alıştırmanın yanı sıra başlangıç yaşı ve el tercihi gibi bazı faktörler de uzman performansında etkili olabilmektedir. Yetenek ve alıştırmanın uzman performansındaki rolünü inceledikleri çalışmada araştırmacılar amatör düzeyden büyükusta düzeyine kadar değişen farklı uzmanlık düzeylerindeki satranç oyuncularını satranca başlangıç yaşı, el tercihi, bireysel ve grup alıştırmaları açısından karşılaştırmışlardır. Buna göre, el tercihi ve satranç performansı arasında anlamlı bir ilişki ortaya çıkmazken, hem bireysel hem de grup alıştırma miktarı satranç performansıyla ilişkili olmuştur. Satranç performansını anlamlı bir şekilde yordayan değişkenler ise grup alıştırma miktarı ve antrenörlük/eğitmenlik olmuştur. Buna rağmen araştırmacılar alıştırmanın uzman performansı için gerekli ancak yeterli olmadığını, el tercihi ve satranca başlangıç yaşı gibi faktörlerin de etkili olabileceğini belirtmişlerdir. Ancak, yapılan bu çalışmada elde edilen bulgular değerlendirilirken çalışmada incelenen alıştırma aktivitelerinin kasıtlı alıştırmadan ziyade normal alıştırma aktivitelerine karşılık geldiğine dikkat etmek gerekmektedir.

Satranç performansı ile kasıtlı alıştırma miktarı arasındaki ilişkiyi satranç çalışmalarındaki bulguları yeniden analiz ederek inceleyen Hambrick ve arkadaşları (2014) kasıtlı alıştırma miktarı ve satranç performansı arasında yüksek bir ilişki bulsa da, kasıtlı alıştırmanın satranç performansına ilişkin varyansın sadece \%34'ünü açıkladığını belirterek kasıtlı alıştırmanın satranç performansındaki bireysel farklılıkları açıklamada yeterli olmadığını öne sürmüştür. Buna göre, araştırmacılar satranç performansında kasıtlı alıştırmanın yanı sıra başlangıç yaşı, zekâ, kişilik ve genetik faktörlerin de uzman performansında etkili olabileceğini belirtmiştir.

Uludağ Üniversitesi Fen-Edebiyat Fakültesi Sosyal Bilimler Dergisi Uludağ University Faculty of Arts and Sciences Journal of Social Sciences

Cilt: 19 Sayı: 34 / Volume: 19 Issue: 34 


\section{Spor Alanındaki Çalışmalar}

Kasıtlı alıştırmanın uzman performansındaki rolünün incelendiği temel alanlardan bir diğeri de spor olmuştur. Müzik ve satranç gibi alanlardaki uzman performansında kasıtlı alıştırmanın önemli bir rolü olduğuna işaret eden çalışmalardan sonra araştırmacılar kasıtlı alıştırma kuramının spor alanına da uygulanıp uygulanamayacağını incelemeye başlamışlardır. Yapılan bu çalışmalarda kişilerin gerçekleştirdiği alıştırma türleri ve miktarları ile performans düzeyleri arasındaki ilişkiyi inceleyen araştırmacılar, kasıtlı alıştırmanın rolünü yüzme (Weir vd. 2002), koşu (Young ve Salmela 2010), triatlon (Baker vd. 2005), dart (Duffy vd. 2004), karate (Hodge 1997), güreş (Hodges 1995), artistik buz pateni (Deakin ve Cobley 2003), golf (Hayman 2012) gibi bireysel sporlar ile futbol (Helsen vd. 1998; Ford vd. 2009; Coughlan vd. 2013), buz hokeyi (Soberlak ve Cote 2003), çim hokeyi, netbol ve basketbol (Baker vd. 2003) gibi takım sporları açısından da incelemiştir.

Kasıtlı alıştırma kuramını spor alanında test eden ilk çalışmalardan biri Hodges (1995) tarafından yapılmıştır. Yapılan bu çalışmada, amatör ve uluslararası düzeydeki güreş̧̧iler güreşe başladıkları ilk yıldan itibaren güreşle ilgili gerçekleştirdikleri aktiviteler (tek başına alıştırma yapma, diğerleriyle birlikte alıştırma yapma, güreşle ilgili diğer aktiviteler) açısından karşılaştırılmıştır. Ayrıca, katılımcılar bu aktiviteleri performans geliştirmeyle ilişsisi, çaba gerektirmesi ve eğlenceli/keyifli olup olmaması açısından da değerlendirmiştir. Yapılan bu çalışmada, amatör ve uluslararası düzeydeki güreşçileri birbirinden ayıran alıştırma türü diğerleriyle birlikte yapılan alıştırma olmuştur. Birikimli alıştırma miktarları açısından incelendiğinde, güreşe başladıktan 10 yıl sonra uluslararası gruptaki güreşçilerin diğeriyle birlikte yaptıkları birikimli alıştırma miktarı 5800 saat civarında olurken, amatör gruplarda bu süre 3500 saat civarında olmuştur. Güreş aktivitelerinin değerlendirilmesine bakıldığında, performans geliştirmeyle ilişkili olarak değerlendirilen aktivitelerin konsantrasyon ve eğlence düzeyi açısından da yüksek 
değerlendirildiği görülmüştür. Kasıtlı alıştırma kuramını spor alanında test eden bu çalışma bulgularını Ericsson ve arkadaşlarının (1993) müzik alanındaki çalışma bulgularıyla karşılaştırdığımızda, en temel farklılıklardan biri Hodges (1995) tarafindan yapılan bu çalışmada tek başına alıştırma aktivitelerinin değil diğerleriyle birlikte yapılan aktivitelerin uzman ve amatörleri birbirinden ayırt etmesidir. Ayrıca, kasıtlı alıştırma aktivitelerinin değerlendirilmesinde performansı geliştiren ve konsantrasyon gerektiren aktivitelerin aynı zamanda eğlence düzeyleri açısından da yüksek değerlendirilmesi ortaya çıkan bir diğer farklilıktır.

Kasıtlı alıştırma kuramını takım oyunları açısından inceleyen ilk çalışmalardan biri ise Helsen ve arkadaşları (1998) tarafından yapılmıştır. Yapılan bu çalışmada alıştırma ve performans arasındaki ilişkinin futbol ve çim hokeyi gibi takım oyunları için de geçerli olup olmadığı test edilmiştir. Ayrıca, takım oyunlarındaki aktivitelerin ilgililik, çaba ve eğlence düzeyleri açısından değerlendirilmesinin kasıtlı alıştırma kuramının varsayımlarıyla tutarlı olup olmadığı da incelenmiştir. Her iki takım oyunu açısından da bireysel ve takımla yapılan alıştırma miktarının her ikisinin de performans düzeyiyle ilişkili olduğu görülse de takımla yapılan alıştırma miktarının farklı uzman gruplarını daha iyi ayırt ettiği görülmüştür. Futbol açısından değerlendirildiğinde, gözlenen örüntülerden biri kariyer yılının artmasıyla birlikte bireysel alıştırma miktarlarının azalması, takımla yapılan alıştırma miktarlarının ise artması olmuştur. Futbolda 18 yıllık bir kariyerin ardından oyuncuların birikimli alıștırma miktarları incelendiğinde, uluslararası oyuncuların toplam alıştırma miktarı 9300 saat civarında olurken, ulusal oyuncularda 7400 saat civarında, yerel oyuncularda ise 5000 saat civarında olmuştur. Çim hokeyi açısından değerlendirildiğinde ise, uluslararası düzeydeki oyuncuların kariyerleri boyunca ulusal ve yerel oyunculara göre bireysel alıştırmaya daha fazla zaman harcadıkları görülmüştür. Ayrıca hem uluslararası düzeydeki oyuncular hem de ulusal düzeydeki oyuncular yerel düzeydeki oyunculara göre takımla yapılan alıştırmaya daha fazla zaman 
harcamışlardır. Çim hokeyinde 18 yıllık bir kariyerin ardından oyuncuların birikimli alıştırma miktarları incelendiğinde ise, uluslararası oyuncuların toplam alıştırma miktarı 10200 saat civarında olurken, ulusal oyuncularda 9000 saat civarında, yerel oyuncularda ise 6000 saat civarında olmuştur. Alıştırma aktivitelerinin değerlendirilmesiyle ilişkili sonuçlara bakıldığında ise, performans geliştirmeyle en ilgili olarak değerlendirilen aktivitelerin aynı zamanda en eğlenceli aktiviteler olarak da değerlendirildiği görülmüş̧tür.

Çeşitli spor dallarında alıştırma yapmanın uzman performansındaki rolünün incelendiği diğer çalışmalar da bireylerin alıştırma miktarı ile performans düzeyleri arasında bir ilişki olduğunu ve alıştırma miktarlarının farklı düzeydeki uzmanlık gruplarını birbirinden ayırt ettiğini desteklemektedir (Ford vd. 2009; Duffy vd. 2004; Ward vd. 2007). Ancak, performansı yordayan alıştırma türünün spor dalına göre farklılaştığı görülmektedir. Örneğin, dart gibi bireysel sporlarda üstün performans tek başına yapılan alıştırmalara katılımla ilişkili olurken (Duffy vd. 2004), futbol gibi takım oyunlarında takımla yapılan kasıtlı alıştırmalara katılım üstün performans ile daha yakından ilişkili olmaktadır (Ward vd. 2007).

Yapılan çalışmalar uzmanların yaptıkları alıştırmaların sadece miktar açısından değil, içerik açısından da farklılaştığııı göstermektedir. Baker ve arkadaşları (2003) tarafından yapılan ve takım oyunlarındaki uzman karar vericilerde farklı alıştırma türleri ve miktarları açısından uzman ve uzman olmayan oyuncular arasındaki farklılıkların incelendiği bir çalışmada, uzman oyuncular uzman olmayan oyunculara göre sadece daha fazla alıştırma yapmakla kalmamış, bu alıştırmalar sırasında belirli aktivitelere (örneğin, video izleyerek alıştırma yapma, organize takım çalışması, antrenörle bireysel çalışma gibi) daha fazla yer vermiş̧lerdir. Baker ve arkadaşları (2005) tarafından yapılan bir başka çalışmada ise, aşırı dayanıklılık gerektiren triatlonda uzman ve uzman olmayan triatletlerin alıştırma miktarı ve türleri incelendiğinde uzmanların hem nicelik hem de nitelik açısından daha iyi alıştırma yaptıklarına işaret eden sonuçlar elde edilmiştir. 
Yapılan bu çalışmada, uzmanların daha sistematik ve ilerleyici alıştırmalar yaptı̆̆ 1 ve alıştırmalar sırasında çaba sarf etme açısından da daha dengeli bir dağılım yaptıkları görülmüştür. Buna göre, uzman triatletler spora özgü aktivitelere daha fazla katılmış, alıştırma miktarlarını yıldan yıla arttırmış ve alıştırmalarını yüksek stres yaratan aktivitelerden sonra daha düşük stresli aktiviteler gelecek şekilde tasarlamışlardır.

Uzman ve amatör oyuncuların yaptıkları alıştırma aktivitelerinin içerik açısından farklılaştı̆̆ını deneysel bulgularla destekleyen çalışmalar da bulunmaktadır. Coughlan ve arkadaşlarının (2013) uzman ve orta düzeydeki gal futbolu oyuncularıyla laboratuvar ortamında yaptıkları bir çalışma, uzmanların alıştırma yaparken daha önce zayıf olduklarını düşündükleri becerilere daha fazla ağırlık verirken, orta düzeydeki oyuncuların zaten güçlü olduklarını düşündükleri becerilere daha fazla ağırlık verdiğini göstermektedir. Uzman ve amatör oyuncuların gerçekleştirdikleri aktivitelerin performans gelişimiyle ilişkisi karşılaştırıldığında ise, hem uzman oyuncular hem de amatör oyuncular alıştırma aşamasında ağırlıklı olarak gerçekleştirdiği vuruşlarındaki performanslarını arttırsalar da, performanstaki değişimin sadece uzman oyuncularda sürdürüldüğü görülmüştür. Yapılan bu çalışma uzmanların kasıtlı alıştırma aktivitelerini performansı geliştirmek amacıyla yaptıklarını ve bu alıştırmalar sırasında performanstaki eksiklikleri gidermeye yönelik alıştırmalar yaptıklarını deneysel bulgularla desteklemesi açısından oldukça önemlidir.

\section{ÇALIŞMALARDAKİ YÖNTEMSEL FARKLILIKLAR VE EKSIKKLIKLLR}

Farklı uzmanlık alanlarındaki çalışmalarda en tartışmalı konulardan biri kasıtlı alıştırma aktivitelerinin tanımlanmasıdır. Kuramsal olarak baktığımızda, kasıtlı alıştırma aktiviteleri performansı geliştirmek için özel olarak tasarlanmış, yoğun çaba ve konsantrasyon gerektiren alıştırma aktiviteleri olarak tanımlanmaktadır (Ericsson vd. 
1993: 368). Bu aktivitelerde kişilerin geribildirimlere ve tekrarlara bağl1 olarak ustalaşabileceği görevler yer almaktadır (Ericsson 2006: 692). Ancak uygulama açısından bakıldığında, farklı uzmanlık alanlarındaki uygulamalarda bu tanıma karşıllı gelecek alıştırma aktivitelerini bulmak zor olabilmektedir. Kasıtlı alıştırma kuramının ortaya atıldığ çalışmada Ericsson ve arkadaşları (1993), kariyerlerine solo performans göstererek devam edecek klasik müzik çalan öğrencilerin alıştırma aktivitelerini incelemişlerdir. Dolayısıyla, bu gruptaki kişiler için tek başına alıştırma yaptıkları çalışmalar performanslarının gelişimi için önemli olabilmektedir. Müzik ile ilgili alanlarda tek başına alıştırma yapma kasıtll alıştırma aktiviteleri olarak değerlendirilse de "deşifre (sight-reading)" ya da "eşlik ederek çalma" ile ilişkili performanslar söz konusu olduğunda tek başına alıştırmadan ziyade eşlik ederek çalma alıştırmaları performans gelişimiyle daha ilişkili aktiviteler olabilmektedir (Lehmann ve Ericsson 1996). Dolayısiyla, bu çalışmalarda eşlik ederek çalma alıştırmalarının kasıtlı alıştırmaları daha iyi yansıttığı söylenebilir. Satranç ile ilgili çalışmalara baktığımızda da satranç oyuncularının tek başına ciddi alıştırma saatleri kasıtlı alıştırma aktiviteleri olarak değerlendirilebilmektedir. Çünkü bu alıştırma aktivitelerinde oyuncular büyükusta düzeyindeki satranç oyuncularının oynadıkları oyunları adım adım analiz ederek kendi hamleleriyle büyükustaların hamlelerini karşılaştırmakta ve aradaki farklılıkları dikkatli bir şekilde değerlendirmektedir (Ericsson 2006). Oysaki satrançla ilişkili çalı̧̧malarda kasıtlı alıştırmanın etkisini inceleyen çalışmalar arasında tek başına ciddi alıştırma saatleri yerine satranç programlarını kullanma ya da satrançla ilgili sahip olunan kitap sayısı gibi değişkenleri bireysel çalışma aktiviteleri olarak değerlendiren çalışmalar da vardır (Campitelli ve Gobet 2008). Bu durum kasitlı alıştırma olarak değerlendirilen aktivitelerin çalışmalar arasında farklılaştığını göstererek çalışmalarda elde edilen bulgulardaki farklıların da bununla ilişkili olabileceğine işaret etmektedir. Sporla ilgili çalışmalara baktığımızda da, tek başına alıştırma yapma aktiviteleri dart gibi bireysel sporlarda performansı geliştiren önemli aktiviteler olarak karşımıza çıksa da (Duffy vd. 2004) aynı durumun 
takım sporları için geçerli olmadığına işaret eden çalışmalar olmuştur (Ward vd. 2007). Sonuç olarak, kasitlı alıştırma aktiviteleri alana özgü aktivitelerdir ve ilişkili olduğu uzmanlık alanına bağlı olarak da değişebilmektedir. Dolayısıyla, yapılan araştırmalarda bunu dikkate alarak kasıtlı alıştırma aktivitelerini belirlemek gerekmektedir. $\mathrm{Bu}$ yüzden, kasıtlı alıştırmanın uzman performansındaki etkisinin incelendiği çalışmaların değerlendirilmesinde öncelikli olarak dikkat edilecek konu da çalışmada ifade edilen kasıtlı alıştırma aktivitelerinin nasıl tanımlandığı ve nasıl ölçüldüğü olmalıdır.

Farklı uzmanlık alanlarındaki çalışmalarda kasıtlı alıştırma ile ilişkili olan bir diğer tartışmalı konu alıştırma aktivitelerinin 3 boyutu (performans geliştirmeyle ilişkili olması, çaba ve konsantrasyon gerektirmesi, doğası gereği eğlenceli/keyifli olmaması) açısından değerlendirilmesidir. Performans ile ilişkili olması ve çaba gerektirmesi ile ilgili boyutlarda araştırmalarda tutarlı sonuçlar elde edilse de özellikle aktivitelerin eğlence düzeyi açısından değerlendirilmesinde çelişkili bulgular vardır. Ericsson ve arkadaşları (1993: 368), kasıtlı alıştırma aktivitelerinin kendisinin yoğun çaba gerektiren ve tekrarlayan alıştırmalardan oluştuğu için doğası gereği eğlenceli/keyifli olmayacağını öne sürmüsstür. Ancak, özellikle spor alanında yapılan çalışmalarda katılımcılar performansı geliştiren aktiviteleri aynı zamanda eğlence düzeyi açısından da yüksek olarak değerlendirmektedir (Hodges 1995; Helsen vd. 1998; Deakin ve Cobley 2003). Bu farklılıkların ortaya çıkmasının sebeplerinden biri alıştırmanın kendisinin değil sonucunun ne kadar eğlenceli/keyifli olduğuna bağlı olarak değerlendirilmesi olabilmektedir. Ericsson ve arkadaşları (1993: 368) aktivitelerinin eğlence boyutu değerlendirilirken aktivitenin sonucunun değil, o aktivitenin gerçekleşme anının değerlendirilmesi gerektiğgine özellikle dikkat çekmiş olsalar da yapılan çalışmalarda aktivitenin sonucu da katılımcının o aktiviteyi değerlendirmelerini etkileyebilmektedir. Özellikle takım oyunlarındaki sporlarda alıştırma aktivitelerinin diğer insanlarla birlikte gerçekleşiyor olması da bu aktivitenin eğlence düzeyi açısından değerlendirilmesini 
etkileyebilmektedir. Ayrıca, çalışmalarda çelişkili bulguların ortaya çıkması elde edilen verilerin çoğunlukla geriye yönelik olarak elde edilip değerlendirilmesiyle de ilgili olabilmektedir. Yapılan bazı çalışmalarda, günlük verileriyle geriye yönelik bilgilerin elde edildiği ölçek verileri karşılaştırıldığında katılımcıların aktiviteleri farklı şekilde değerlendirdiği gösterilmiştir. Örneğin, Hodges ve arkadaşları (2004) tarafından yapılan bir çalışmada günlük verilerinde aktivitenin performans gelişimiyle ilişkisi ve aktivitenin eğlence düzeyi arasında bir ilişki ortaya çıkmazken, geriye yönelik bilgilerin elde edildiği ölçek verilerinde aktivitenin performans gelişimiyle ilişkisi ve aktivitenin eğlence düzeyi arasında pozitif ve yüksek bir korelasyon bulunmuştur. Bunun yanı sıra, aktivitelerin laboratuvar ortamında gerçekleştiği sırada kasıtlı alıştırmanın 3 boyutu açısından değerlendirildiği çalışmalar da kasıtlı alıştırmaların performans gelişimiyle ilişkisi ve çaba gerektirmesi açısından yüksek, eğlence düzeyi açısından düşük değerlendirildiğini desteklemektedir (Hyllegard ve Yamamoto 2005; Hyllegard ve Bories 2008; Coughlan vd. 2013). Yapilan bu laboratuvar çalışmalarında deneyim ve performans artışına bağlı olarak da 3 boyuta ilişkin algının değişebileceğini ve alıştırmanın başlarında eğlence düzeyi düşük olarak değerlendirilen aktivitelerin, bu aktivitelere katılım arttıkça ve bunun sonucunda performans başarısı arttıkça aktivitelerin eğlence düzeyi açısından değerlendirilmelerinin de arttığını göstermektedir (Hyllegard ve Yamamoto 2007).

Sonuç olarak, kasıtlı alıştırmanın uzman performansındaki rolünü incelerken kasıtlı alıştırmanın nasıl tanımlandığı, nasıl ölçüldüğü, hangi gruplar arasında karşılaştırma yapıldığı, seçilen uzmanların hangi kriterler doğrultusunda seçildiği gibi faktörler oldukça önemlidir. Yapılan çalışmalarda farklı sonuçların elde edilmesinde bu faktörler önemli bir rol oynamaktadır. Dolayısıyla, yapılan çalışmalarda elde edilen bulgular değerlendirirken bu faktörleri de dikkate almak gerekmektedir. 


\section{SONUÇ VE ÖNERILLER}

Olağanüstü ya da üstün becerilere sahip insanları diğer insanlardan ayıran özellikleri anlamaya ve açıklamaya çalışmak uzmanlık çalışmalarının temel amacı olmuştur. Her ne kadar olağanüstü becerileri doğal yeteneğe atfederek açıklama eğilimi olsa da yapılan bilimsel çalışmalarla birlikte deneyim ve eğitim ya da alıştırma yapma gibi faktörlerin de önemli olduğu görülmüştür. Simon ve Chase (1973) tarafindan yapılan ve uzman performansında deneyimin oldukça önemli bir rolü olduğuna dikkat çeken öncü çalışma uzman performansında gözlemlediğimiz üstün becerilerin edinebilir bir beceri olabileceğine işaret etmiştir. Uzman performansında deneyim ve alıştırmanın rolü Ericsson ve arkadaşlarının (1993) öne sürdüğü kasıtlı alıştırma kuramıyla sadece deneyimin değil, belirli türde yapılan ve uzun yıllar devam ettirilen alıştırmaların, yani kasıtlı alıştırma aktivitelerinin, uzman performansında daha önemli olduğunun öne sürülmesiyle birlikte daha ileri bir boyuta taşınmıştır. Böylece, uzman performansın yani ustalığın arkasındaki sır perdesi gittikçe aralanmaya ve gerçekler ortaya çıkmaya başlamıştır.

Bugüne kadar yeteneğe atfedilen birçok özelliğin uzun y1llar yapılan kasıtlı alıştırmaların bir sonucu olabileceğine işaret eden kasıtlı alıştırma kuramı müzik, satranç ve spor başta olmak üzere birçok farklı uzmanlık alanları açısından incelenmiştir. Uzmanlık alanları farklılaşsa da yapılan çalışmalar ortak bir gerçeğe işaret etmiştir. Çalışma bulgularının işaret ettiği bu gerçek de "bireylerin kasıtlı alıştırma miktarlarıyla uzman performansları arasında güçlü bir ilişki" olduğudur. Yani, gerek müzik gerek spor gerekse satranç alanlarında olağanüstü ya da üstün başarılara sahip kişilerin alanlarında çok yetenekli olduğu için değil, uzun yıllar boyunca performanslarını geliştirmek amacıyla saatlerce alıştırma yaptığ 1 için bu düzeylere gelmiş olabileceği görülmektedir. Her ne kadar uzmanlık çalışmalarında alıştırma miktarı ve performans arasında bir ilişki olduğu gösterilse de kasıtlı alıştırmada niteliğin de en az nicelik kadar önemli olduğu unutulmamalıdır. Yani, belirli bir uzmanlık alanına ilişkin alıştırmayı "ne kadar" süre yaptığınla 
birlikte "nasıl" bir alıştırma yaptığın da uzman performansı açısından önemlidir. Kasıtlı alı̧̧̧ırma kuramında da belirtildiği gibi, kasıtlı alıştırma aktiviteleri iş, oyun ya da belirli bir aktivitenin basit bir şekilde tekrar edilmesi gibi diğer aktivitelerden farklılaşmaktadır (Ericsson vd. 1993). Dolayısıyla, yapabildiğimiz bir şeyi aynı şekilde saatlerce tekrar etmekten ziyade, performansımızda eksik olduğumuz, geliştirmek istediğimiz yönlerimize odaklanıp bu eksiklikleri gidermeye yönelik alıştırmalar yapmak üstün başarıya ve ustalığa ulaşmada daha önemlidir.

Müzik, satranç ve spor gibi profesyonel alanlarda yapılan birçok çalışmada kasıtlı alıştırma ve uzman performansı arasında güçlü bir ilişki olduğu gösterilse de bu çalışmaların büyük bir çoğunluğu korelasyonel çalışmalardır. Dolayısıyla, varolan bu korelasyonel çalışma bulgularına dayanarak kasıtlı alıştırma ve uzman performansı arasında bir neden sonuç ilişkisi kuramayız. Ancak, kasıtlı alıştırmanın uzman performansındaki rolünü deneysel yöntemlerle inceleyen çalışmalar da gittikçe artmaktadır. Yapılan bu deneysel çalışmalarda performansı geliştirmek için özel olarak tasarlanan ve uzun süre devam ettirilen alıştırmaların performans üzerinde etkisi olduğunu destekleyen sonuçların elde edildiği görülmektedir (Dalkıran 2011; Özer ve Yiğit 2011). Kasıtlı alıştırma aktivitelerini, aktivitenin gerçekleştiği sırada laboratuvar ortamında inceleyen çalışmalar da bulunmaktadır (Hyllegard ve Yamamoto 2005; Hyllegard ve Bories 2008; Coughlan vd. 2013). Örneğin, Coughlan ve arkadaşları (2013) tarafından yapılan çalışmada, uzman sporcuların daha önceki performanslarında eksik olduğunu düşündükleri becerilere kasıtlı alıştırma aktivitelerinde daha fazla ağırlık verdikleri, amatör sporcuların ise daha önceki performanslarında zaten güçlü olduğunu düşündükleri becerilere daha fazla ağırlık verdikleri görülmüştür. Kasıtlı alıştırma aktivitelerinin performansı geliştirmeye yönelik yapılan aktiviteler olduğunu ya da uzman ve amatör grupların aktivitelerinin nitelik açısından farklılık gösterdiğini deneysel olarak desteklemesi açısından bu bulgular uzmanlık çalışmalarında önemlidir. İleride yapılacak deneysel 
çalışmalarda buna benzer laboratuvar çalışmaları yapılarak farklı uzmanlık alanlardaki kasıtlı alıştırma aktiviteleri de daha yakından incelenebilir ve böylece kasıtlı alıştırma ve uzman performansı arasındaki ilişki daha iyi anlaşılabilir.

Kasıtlı alıştırma ve uzman performansı arasındaki ilişkinin incelendiği çalışmalarda genellikle aynı uzmanlık alanları (örneğin, müzik, spor ya da satranç gibi) kullanılmıştır. Oysaki uzmanlık çalışmalarının ilk ortaya çıktığı yıllarda araştırmacılar farklı uzman grupları arasında ortak özellikler bulmaya çalışmaktaydı. Örneğin, Bloom (1985) tarafından yapılan ilk uzmanlık çalışmalarından birinde birçok farklı alandaki (konser piyanosu, heykel, yüzme, tenis, matematik, araştırma nörolojisi) olağanüstü başarı gösteren bir grup insan incelenerek farklı uzmanlık alanları arasındaki ortak özellikler belirlenmeye çalışılmıştır. Eğer kasıtlı alıştırmanın uzman performansındaki rolü uzmanlık alanından bağımsız bir şekilde ortaya çıkabiliyorsa, deneysel çalışmalarda da buna benzer şekilde aynı çalışmada farklı uzman grupları kullanılarak da çalışmalar yapılabilir. İleride yapılacak bu çalışmalarda uzman gruplarında kendi içinde ve gruplar arasında karşılaştırmalar yapılarak uzman performansında kasıtlı alıştırmanın etkisinde ortak mekanizmaların belirlenmesine ilişkin de önemli sonuçlar elde edilebilir.

\section{KAYNAKLAR}

Baker, Joseph vd. (2005). "Expertise in Ultra-endurance Triathletes Early Sport Involvement, Training Structure, and the Theory of Deliberate Practice". Journal of Applied Sport Psychology, C. 17, S. 1, s. 64-78.

Baker, Joseph vd. (2003). "Sport-Specific Practice and the Development of Expert Decision-Making in Team Ball Sports". Journal of Applied Sport Psychology, C. 15, S. 1, s. 12-25

Bruin, Anique vd. (2008). "Deliberate Practice Predicts Performance Over Time in Adolescent Chess Players and Drop-Outs: A Linear 
Mixed Models Analysis". British Journal of Psychology, C. 99, S. 4, s. 473-497.

Bloom, Benjamin Samuel (Ed.) (1985). Developing Talent in Young People. New York: Ballantine Books.

Campitelli, Guillermo ve Fernand Gobet (2008). "The Role of Practice in Chess: A Longitudinal Study". Learning and Individual Differences, C. 18, S. 4 , s. $446-458$.

Charness, Neil vd. (2005). "The Role of Deliberate Practice in Chess Expertise". Applied Cognitive Psychology, C. 19, S. 2, s. 151-165.

Charness, Neil vd. (1996). "The Role of Practice and Coaching in Entrepreneurial Skill Domains: An International Comparison of LifeSpan Chess Skill Acquisition". Ed: Ericsson, Anders K. The Road to Excellence: The Acquisition of Expert Performance in the Arts and Sciences, Sports, and Games Mahwah: Erlbaum içinde s. 51-80.

Chi, Michelene T. H. (2006). "Two Approaches to the Study of Experts' Characteristics". Eds: Ericsson, Anders K. vd. The Cambridge Handbook of Expertise and Expert Performance Cambridge: Cambridge University Press içinde s. 21-30.

Colvin, Geoff (2008). Talent is Overrated: What Really Separated World-Class Performers From Everybody Else. London: Penguin Books.

Coughlan, Edvard K. vd. (2014). "How Experts Practice: A Novel Test of Deliberate Practice Theory". Journal of Experimental Psychology: Learning, Memory, and Cognition, C. 40, S. 2, s. 449-458.

Dalkıran, Esra (2011). "Keman Eğitiminde Deşifre Becerisi”. Mehmet Akif Ersoy Üniversitesi Sosyal Bilimler Enstitüsü Dergisi, S. 4, s. 54-63.

Deakin, Janice M. ve Stephen Cobley (2003). "A Search for Deliberate Practice: An Examination of the Practice Environments in Figure Skating and Volleyball". Ed: Starkes, Janet L. ve Ericsson, Anders K.,

Uludağ Üniversitesi Fen-Edebiyat Fakültesi Sosyal Bilimler Dergisi Uludağ University Faculty of Arts and Sciences Journal of Social Sciences Cilt: 19 Sayı: 34 / Volume: 19 Issue: 34 
Expert Performance in Sport: Recent Advances in Research on Sport Expertise, United States: Human Kinetics içinde s. 115-135.

De Groot, Adrian D. (1978). Thought and Choice in Chess. Çev: Gruyter, Walter, Netherlands: Mouton Publishers (Orjinal çalışma basim tarihi 1965).

Duffy, Linda J. vd. (2004). "Dart Performance as a Function of Facets of Practice amongst Professional and Amateur Men Ana Women Players". International Journal of Sport Psychology, S. 35, s. 232-245.

Ericsson, Anders K. (2006). "The Influence of Experience and Deliberate Practice on the Development of Superior Expert Performance". Ed: Ericsson, Anders K. vd., The Cambridge Handbook of Expertise and Expert Performance, Cambridge: Cambridge University Press içinde s. 683-703.

Ericsson, Anders K. ve Neil Charness (1994). "Expert Performance: Its Structure and Acquisition". American Psychologist, C. 49, S. 8, s. 725747.

Ericsson, Anders K. vd. (1993). "The Role of Deliberate Practice in the Acquisition of Expert Performance". Psychological Review, C. 100, S. 3, s. 363-406.

Ericsson, Anders K. ve Jacqui Smith (1991). "Prospects and Limits of the Empirical Study of Expertise: An Introduction". Ed: Ericsson, Anders K. ve Smith, Jacqui, Toward a General Theory of Expertise: Prospects and Limits, Cambridge: Cambridge University Press içinde s. 1-39.

Ericcson, Anders K. vd. (1980). "Acquisition of a Memory Skill”. Science, C. 208, S. 4448, s. 1181-1182.

Ford, Paul R. vd. (2009). "The Role of Deliberate Practice and Play in Career Progression in Sport: The Early Engagement Hypothesis". High Ability Studies, C. 20, S. 1, s. 65-75.

Uludağ Üniversitesi Fen-Edebiyat Fakültesi Sosyal Bilimler Dergisi Uludağ University Faculty of Arts and Sciences Journal of Social Sciences Cilt: 19 Sayı: 34 / Volume: 19 Issue: 34 
Gobet. Fernans ve Guillermo Campitelli (2007). "The Role of DomainSpecific Practice, Handedness and Starting Age in Chess". Developmental Psychology, C. 43, S. 1, s. 159-172.

Hambrick, David Z. vd. (2014). "Deliberate Practice: Is That All It Takes to Become an Expert?”. Intelligence, C. 45, s. 34-45.

Hayman, Rick (2012). The Role of Deliberate Practice in Developing Adolescent Golfing Excellence. Doctoral thesis. Lancashire: University of Central Lancashire.

Hearst, Eliot ve John Knott (2008). Blindfold Chess: History, Psychology, Techniques, Champions, World Records, and Important Games. Jefferson: McFarland.

Helsen, Werner vd. (1998). "Team Sports and the Theory of Deliberate Practice". Journal of Sport \& Exercise Psychology, C. 20, S. 1, s. 1234.

Hodge, Tahana (1997). Deliberate Practice and Expertise in the Martial Arts: The Role of Context in Motor Recall. Master Thesis. Kingston: Queen's University.

Hodges, Nicola Jane vd. (2004). "Predicting Performance Times from Deliberate Practice Hours for Triathletes and Swimmers: What, When, and Where is Practice Important?". Journal of Experimental Psychology: Applied, C. 10, S. 4, s. 219-237.

Hodges, Nicola Jane (1995). Wrestling with the Nature of Expertise: A Sport Specific Test of Ericsson, Krampe and Tesch-Römer's (1993) Theory of Deliberate Practice. Master Thesis. Hamilton: McMaster University.

Horgan, Dianne ve David Morgan (1990). "Chess Expertise in Children". Applied cognitive psychology, C. 4, S. 2, s. 109-128.

Hyllegard, Randy ve Tamara L. Bories (2008). "Deliberate Practice Theory: Relevance, Effort, and Inherent Enjoyment of Music Practice". Perceptual and Motor Skills, C. 107, S. 2, s. 439-448. 
Hyllegard, Randy ve Masayuki Yamamoto (2007). "Testing Assumptions of Deliberate Practice Theory Relevance, Effort, and Inherent Enjoyment of Practice with a Novel Task: Study II". Perceptual and Motor Skills, C. 105, S. 2, s. 435-446.

Hyllegard, Randy ve Masayuki Yamamoto (2005). "Testing Assumptions of Deliberate Practice Theory, Relevance, Effort, and Inherent Enjoyment of Practice on a Novel Task". Perceptual and Motor Skills, C. 101, S. 1, s. 283-294.

Krampe, Ralf ve Anders K. Ericsson (1996). "Maintaining Excellence: Deliberate Practice and Elite Performance in Young and Older Pianists". Journal of Experimental Psychology: General, C. 125, S. 4, s. 331-359.

Lehmann, Andreas C. ve Anders K. Ericsson (1998). "Preparation of a Public Piano Performance: The Relation between Practice and Performance". Musicae Scientiae, C. 2, S. 1, s. 67-94.

Lehmann, Andreas C. ve Anders K. Ericsson (1996). "Performance without Preparation: Structure and Acquisition of Expert Sight-Reading and Accompanying Performance". Psychomusicology: A Journal of Research in Music Cognition, C. 15, S. 1-2, s. 1-29.

Meinz, Elizabeth J. ve David Z. Hambrick (2010). "Deliberate Practice is Necessary but Not Sufficient to Explain Individual Differences in Piano Sight-Reading Skill: The Role of Working Memory Capacity". Psychological Science, C. 21, S. 7, s. 914-919.

Özer, Burcu ve Nalan Yiğit (2011). "Piyano Öğretiminde Deşifre Becerisinin Kazandırılması”. Eskişehir Osmangazi Üniversitesi Sosyal Bilimler Dergisi, C. 12, S. 1, s. 39-49.

Platz, Friedrich vd. (2014). "The Influence of Deliberate Practice on Musical Achievement: A Meta-Analysis". Frontiers in Psychology, C. 5, s. 1-13.

Uludağ Üniversitesi Fen-Edebiyat Fakültesi Sosyal Bilimler Dergisi Uludağ University Faculty of Arts and Sciences Journal of Social Sciences Cilt: 19 Sayı: 34 / Volume: 19 Issue: 34 
Ruthsatz, Joanne vd. (2008). "Becoming an Expert in the Musical Domain: It Takes More Than Just Practice". Intelligence, C. 36, S. 4, s. 330-338.

Simon, Herbert ve William Chase (1973). "Skill in Chess: Experiments with Chess-Playing Tasks and Computer Simulation of Skilled Performance Throw Light on Some Human Perceptual and Memory Processes". American Scientist, C. 61, S. 4, s. 394-403.

Soberlak, Peter ve Jean Cote (2003). "The Developmental Activities of Elite Ice Hockey Players". Journal of Applied Sport Psychology, C. 15, S. 1, s. 41-49.

Sloboda, John A. vd. (1996). "The Role of Practice in the Development of Performing Musicians". British Journal of Psychology, C. 87, S. 2, s. 287-309.

Ward, Paul vd. (2007). "The Road to Excellence: Deliberate Practice and the Development of Expertise". High Ability Studies, C. 18, S. 2, s. 119-153.

Weir, Patricia L. vd. (2002). "Master Swimmers: How are They Different from Younger Elite Swimmers? An Examination of Practice and Performance Patterns". Journal of Aging \& Physical Activity, C. 10, S. 1, s. 41-63.

Young, Bradley W. ve John H. Salmela (2010). "Examination of Practice Activities Related to the Acquisition of Elite Performance in Canadian Middle Distance Running". International Journal of Sport Psychology, C. 41, S. 1, s. 73-90.

Uludağ Üniversitesi Fen-Edebiyat Fakültesi Sosyal Bilimler Dergisi Uludağ University Faculty of Arts and Sciences Journal of Social Sciences Cilt: 19 Sayı: 34 / Volume: 19 Issue: 34 